\title{
Pedomorphosis revisited: thyroid hormone receptors are functional in
}

\section{Necturus maculosus}

\author{
Rachid Safi,a Virginie Vlaeminck-Guillem,a,b Marilyne Duffraisse, a Isabelle Seugnet,c Michelina Plateroti,a \\ Alain Margotat, ${ }^{\mathrm{d}}$ Martine Duterque-Coquillaud,b ${ }^{\mathrm{b}}$ Erica J. Crespi,e Robert J. Denver,e Barbara Demeneix, ${ }^{\mathrm{c}}$ \\ and Vincent Laudeta,*
}

\author{
${ }^{a}$ CNRS UMR 5161, INRA LA 913, Laboratoire de Biologie Moléculaire de la Cellule, IFR128 BioSciences Lyon-Gerland, \\ Ecole Normale Supérieure de Lyon, 46 Allée d'Italie, 69364 Lyon Cedex 07, France \\ ${ }^{\mathrm{b}}$ CNRS UMR 8526, Institut de Biologie de Lille, 1 rue Calmette, B.P. 447, 59021 Lille Cedex, France \\ 'CNRS UMR 5166, Département Régulations, Développement et Diversité Moléculaire, Muséum National d'Histoire \\ Naturelle, 7 rue Cuvier, 75231 Paris Cedex 5, France \\ dINSERM U476, Faculté de Médecine, 27 Boulevard Jean Moulin, 13385 Marseille Cedex 05, France \\ ${ }^{e}$ Department of Molecular, Cellular and Developmental Biology, University of Michigan, 3065C Kraus Natural Science \\ Building, Ann Arbor, MI 48109-1048, USA \\ *Author for correspondence (email: Vincent.Laudet@ens-lyon.fr)
}

SUMMARY Heterochrony, a difference in developmental timing, is a central concept in modern evolutionary biology. An example is pedomorphosis, retention of juvenile characteristics in sexually mature adults, a phenomenon largely represented in salamanders. The mudpuppy (Necturus maculosus) is an obligate pedomorphic amphibian, never undergoing metamorphosis. Thyroid hormone induces tissue transformation in metamorphosing species and this action is mediated by nuclear thyroid hormone (TH) receptors (TRs). The absence of metamorphosis in Necturus has been attributed to a resistance to $\mathrm{TH}$ action as treatment with exogenous $\mathrm{TH}$ fails to induce transformation. The failure to metamorphose could be due to the lack of TR expression in target tissues, or to a loss of TR function. Toward understanding the molecular basis for the failure of Necturus tissues to respond to $\mathrm{TH}$, and the ultimate cause for the expression of the obligate pedomorphic life history, we characterized the structure, function, and expression of TR genes in Necturus. Strikingly, we found that Necturus $T R \alpha$ and $T R \beta$ genes encode fully functional TR proteins. These TRs bind both DNA and TH and can transactivate target genes in response to $\mathrm{TH}$. Both $T R \alpha$ and $T R \beta$ are expressed in various tissues. TH treatment in vivo induced expression in the gill of some but not all genes known to be activated by $\mathrm{TH}$ in anuran larvae, caused whole organism metabolic effects, but induced no external morphological changes in adults or larvae. Thus, Necturus possesses fully functional TRs and its tissues are not generally resistant to the actions of TH. Rather, the absence of metamorphosis may be due to the loss of $\mathrm{TH}$-dependent control of key genes required for tissue transformation.

\section{INTRODUCTION}

Heterochrony, an ancestor-descendent difference in the relative timing of developmental events, is a central concept in modern evolutionary biology (Gould 1977; Mc Namara 1995). Among the various examples of heterochronic changes, pedomorphosis, which refers to the retention of juvenile characteristics in sexually mature adults, has been widely studied in amphibians. Pedomorphosis can either be obligate or facultative, depending on the species. Obligate pedomorphic species never undergo metamorphosis and remain in an aquatic habitat their entire lives. This life-history strategy has been described in six distantly related families of caudate amphibia: Plethodontidae, Sirenidae, Cryptobranchidae,
Amphiumidae, Ambystomatidae (e.g., the Mexican axolotl Ambystoma mexicanum), and Proteidae (e.g., the mudpuppy Necturus maculosus and Proteus anguinus). In these species, pedomorphosis is believed to have evolved through neotenic changes, that is, through the slowing of somatic development with a relative acceleration of gonadal development. It has been proposed that pedomorphosis may be caused either directly or indirectly by the action of natural selection (Hart and Wray 1999). For example, selection can act directly on the relative timing of developmental events such as the timing of metamorphosis. Alternatively, selection can act indirectly on morphological or physiological characters that are important for fitness. In the latter case, trait modifications can indirectly result in pedomorphosis, which may simply be due to devel- 
opmental constraints in the response to natural selection. In the North American ambystomatid salamander complex, which includes both metamorphosing and nonmetamorphosing species, the frequency of pedomorphosis is subject to selection. Voss and Smith (2005) recently showed that a major effect quantitative trait locus contributes to both the incidence of pedomorphosis and to variation in metamorphic timing. This finding has led to the proposal that in facultatively pedomorphic species, the evolution of pedomorphosis occurred gradually via selection for delayed metamorphic timing (Voss and Smith 2005).

Amphibian metamorphosis is a post-embryonic developmental process that is controlled by thyroid hormone (TH). In anuran amphibians (frogs and toads), a peak in plasma $\mathrm{TH}$ coincides with metamorphic climax (Leloup and Buscaglia 1977; Shi 1999; Tata 2000). The biological actions of TH are mediated by two members of the nuclear hormone receptor superfamily, the TH receptors: $\operatorname{TR} \alpha$ and $\operatorname{TR} \beta$ (also known as NR1A1 and NR1A2, respectively). The TRs are ligand-dependent transcription factors that bind to specific hormone response elements located in target gene promoters. During metamorphosis of Xenopus laevis, there is a peak in $\operatorname{TR} \beta$ expression that is coincident with the surge in plasma $\mathrm{TH}$ at metamorphic climax (Kanamori and Brown 1992; Shi 1999). This rise in TR $\beta$ expression is the result of an auto-regulatory loop at the TR $\beta$ locus, which is under direct control by TH (Ranjan et al. 1994; Machuca et al. 1995; Tata 2000). It has been proposed that the $\mathrm{TH}$ peak induces a gene regulation cascade that tightly controls the independent metamorphic changes in various larval tissues (Berry et al. 1998, 1998; Helbing et al. 2003).

In obligate pedomorphic species, such as Necturus or Proteus, reproduction occurs in animals that retain larval characters such as external gills and tail fins (Lynn 1961; Rosenkilde and Ussing 1996). In contrast to the so-called "inducible" obligate pedomorphs such as the Mexican axolotl (Ambystoma mexicanum), these species do not respond to exogenous TH by metamorphosing, and no biochemical changes have been observed in response to TH. However, these socalled "permanent" obligate pedomorphs possess functional thyroid glands, which, when transplanted into other species, can induce metamorphosis, suggesting that they can produce thyroid hormones (Swingle 1922; Charipper 1929; Grant 1930; Harris 1956; Galton and Ingbar 1962). Several reports, using various biochemical and molecular approaches, have suggested that $T R$ expression is very weak or even absent in Necturus tissues and that this species could be a natural case of $\mathrm{TH}$ resistance owing to a lack of receptor expression, or to a failure to upregulate TRs in response to TH (Galton 1985; Yaoita and Brown 1990; Safi et al. 1997). In contrast, resistance to thyroid hormone (RTH) syndromes in humans often arises from mutations in the $T R \beta$ gene that result in the loss of hormone binding and thus the loss of activation function (but not repressor function) of this receptor (Weiss and Refetoff 2000). Thus, the failure of Necturus to metamorphose following treatment with TH could be due to a loss of TR expression or to a loss of TR function or both.

To address these questions, we characterized the thyroid hormone receptors TR $\alpha$ and TR $\beta$ in Necturus. Strikingly, we found that both receptors are active (i.e., able to bind to DNA, to heterodimerize with RXR, to bind $\mathrm{TH}$, and to activate transcription in response to $\mathrm{TH}$ addition) and are expressed in various tissues. $\mathrm{TH}$ treatment induces $\mathrm{TH}$ target gene activation in vivo in adults and reduces growth in larvae, but without inducing morphological changes. Thus, Necturus is not generally resistant to TH. Rather, the absence of metamorphosis may result from insufficient TR expression or action in tissues such as the gill or tail fin, or to the loss of THdependent control of key genes required for tissue transformation.

\section{MATERIALS AND METHODS}

\section{Isolation of full-length Necturus TR cDNAs}

We previously isolated RT-PCR fragments of $T R \alpha$ and $T R \beta$ from Necturus and Proteus, which correspond to the central region of the cDNAs (Safi et al. 1997). Using the sequence information of these previously isolated Necturus RT-PCR fragments, a combination of inverted PCR and 5'-RACE experiments allowed us to isolate the complete coding sequences of each $T R$. To clone the $5^{\prime}$ region of the $T R \alpha \mathrm{cDNA}$, RNA from tail muscle was extracted and a $5^{\prime}$-RACE reaction was performed using the $5^{\prime} / 3^{\prime}$ RACE KIT from Boehringer (Mannheim, Germany) following the supplier's method. The primers used in this experiment are shown in the supplementary Table S1. For the $3^{\prime}$ end part of the cDNA, we performed inverted PCR as described in (Ochman et al. 1988; Triglia et al. 1988). The full-size clones were then re-amplified by RT-PCR using a $5^{\prime}$ primer located close to the ATG start codon and a $3^{\prime}$ primer located in the Stop codon. The sequence of each cDNA was compared with the sequence of the RT-PCR fragments in order to ensure that we effectively cloned the TRs from Necturus. The sequences for the full-size cDNAs are available in GenBank using the following accession numbers: TR $\alpha$ (AY168330) and TR $\beta$ (AY168331).

\section{Electrophoretic mobility shift assays}

Full-length Necturus TR $\alpha$ and TR $\beta$ as well as Xenopus TRs and Xenopus $\mathrm{RXR} \alpha$ proteins were translated in vitro using the TNT Kit (Promega, Madison, WI, USA). A DR4 probe from the Xenopus TR $\beta$ promoter encompassing the transcription start site (positions - 12 to 18) (Machuca et al. 1995) was labeled with T4 polynucleotide kinase in the presence of $\gamma-{ }^{32} \mathrm{P}$ dATP. Binding reactions were performed as described in Safi et al. (2004). Unlabeled competitor oligonucleotides were included in the binding reactions at the indicated molar excess. The sequences of competitors are indicated in the supplementary Table S1. 


\section{TH-binding assay}

The cDNAs encoding Necturus and Xenopus TRs as well as the human $T R \beta$, which was used as a control, were transcribed and translated in vitro using the TNT T7-coupled reticulocyte lysate system (Promega) according to the manufacturer's instructions in the presence or absence of $35 \mathrm{~S}$ methionine $(1000 \mathrm{Ci} / \mathrm{mmol}$; Amersham, Arlington Heights, IL, USA). Using these proteins, the T3 binding affinity was determined according to Safi et al. 2004.

\section{Transient transfection and transactivation assays}

The Necturus TR $\alpha$ and TR $\beta$ cDNA were subcloned into EcoRI/ BamHI sites from a pSG5 vector. Ros 17/2.8 (rat osteosarcoma) cells were plated in Dulbelcco's-modified Eagle's medium (DMEM, Bio Media, Paris, France) supplemented with $10 \%$ fetal calf serum (FCS) at a density of $10^{5}$ cells per dish. Transient transfection assays were performed in triplicate as in Safi et al. 2004.

\section{In situ hybridization}

Samples of $N$. maculosus tissue were obtained from three wild North-American specimens (two males, one female), which were kindly provided by G. Planelles (Necker Hospital, Paris, France). Tissues were fixed in $4 \%$ paraformaldehyde at $4{ }^{\circ} \mathrm{C}$, dehydrated, and embedded in paraffin. Six to eight micrometer sections were mounted on silane-treated glass slides (Sigma, St. Louis, MO, USA). Antisense and sense 35S-labeled RNA probes were prepared from $N$. maculosus $T R \alpha$ and $T R \beta$ cDNAs as well as from the $C T H B P$ and $S T 3$ cDNAs, which were both cloned by RT-PCR using primers recognizing conserved gene regions (data not shown; accession numbers as follows: Stromelysine 3: AY168333; CTHBP: AY168332). The $T R \alpha$ and $T R \beta$ probes used in this study encompass the regions encoding the $\mathrm{C}, \mathrm{D}$, and $\mathrm{E}$ domains of the proteins. The in situ hybridization method used was from Bonnelye et al. (1997). The slides were then exposed for 3-4 weeks (ST3 probes) or 5-7 days (CTHBP probe). After development, they were stained with bisbenzimide (Hoechst $33258^{\circledR}$ intercaling DNA dye, Sigma) and mounted in glycergel (Sebia, Sigma ${ }^{\mathbb{R}}$ ). Control hybridization of similar sections with a sense probe did not produce any specific detectable signal above background.

\section{Immunohistochemistry}

The dissected intestine was fixed in $4 \%$ paraformaldehyde, embedded in paraffin, and $5-\mu \mathrm{m}$ sections were mounted on polylysinecoated slides. For morphological observations, the slides were stained with hematoxylin and eosin. Immunohistochemistry experiments were performed with a polyclonal antibody (anti-TR $\alpha$, PA1-211, Affinity Bioreagents Inc., Golden, CO, USA) as well as with antibodies against Xenopus TR $\alpha$ and TR $\beta$ proteins described in Fairclough and Tata (1997). For TR $\alpha$ staining, we obtained the same result with the two different antibodies. These antibodies have been used in combination with a secondary biotinylated antibody with the streptavidin-peroxidase detection system (Histomouse, Zymed, London, UK).

\section{TH treatment of Necturus and RNA extraction}

Adult Necturus obtained from Lemberger Inc. (Heidelberg, Germany) were maintained in large holding tanks for one week before the start of the experiments. Batches of six randomly chosen animals were transferred in 101 tanks maintained at $10^{\circ} \mathrm{C}$ with a 12L:12D light cycle. Water was changed and hormone was replenished at 2-3-day intervals throughout the experiment. Animals were treated for 1 month at $5 \mathrm{nM}$ or $1 \mu \mathrm{M}$ before tissues were harvested. Animals were given a final hormone treatment $18 \mathrm{~h}$ before sacrifice. Tissues were harvested into RNAlater (Ambion, Pontoise, France). Total RNA was extracted from tissues using the RNAble reagent from Eurobio (Les Ulis, France), following the manufacturer's protocol.

\section{Plasma TH concentrations in Necturus}

To measure plasma $T_{3}$ concentrations, frozen plasma samples were thawed at room temperature and a $50 \mu \mathrm{l}$ aliquot (control, PTUtreated and $5 \mathrm{nM} \mathrm{T}_{3}$-treated groups) or a $2 \mu \mathrm{l}$ aliquot $\left(1 \mu \mathrm{M} \mathrm{T} \mathrm{T}_{3^{-}}\right.$ treated group, to remain in the detection range of the kit) was analyzed for total circulating $\mathrm{T}_{3}$ using the AMERLEX-M $\mathrm{T}_{3}$ RIA kit (Trinity Biotech, Wicklow, Ireland) according to the suppliers' instructions. This kit utilizes a competitive radioimmunoassay technique, using an anti- $\mathrm{T}_{3}$ antibody bound to magnetizable polymer particles. The antibody-bound fraction is separated by magnetic separation, followed by decanting of the supernatant.

\section{Semi-quantitative RT-PCR assay}

One to five micrograms of DNAase-treated total RNA were reverse transcribed using random primers or specific primers and MMLV reverse transcriptase in $20 \mu \mathrm{l}$ of reaction mixture according to the manufacturers' instructions (GibcoBRL, Illkirch, France MMLV-RT kit). The resulting cDNA was amplified by PCR in $50 \mu \mathrm{l}$ volume with $10 \mathrm{~mm}$ Tris- $\mathrm{HCl} \mathrm{pH}: 8.3,50 \mathrm{~mm} \mathrm{KCl}, 1.5 \mathrm{~mm}$ $\mathrm{MgCl}_{2}$ (Perkin-Elmer, Norwalk, CT, USA), $0.25 \mathrm{~mm}$ of each dXTP, 2.5 U Taq Gold DNA polymerase (Perkin-Elmer), and $300 \mathrm{ng}$ of each primer. Specific primers were designed to amplify fragments of the stromelysine 3, TR $\alpha$, TR $\beta$, and 28S rRNA genes. Primers, spanning different exons to avoid interference with DNA contamination, are described in supplementary Table S1. In parallel to each PCR, a PCR reaction was carried out to amplify the 28S rRNA to normalize the quantity of cDNA used for each sample. The RT were carried out with a pool of RNA for each point using the same amount of RNA for each animal. We used a standard PCR protocol consisting of 30 cycles for $T R \alpha, T R \beta$, and 25 cycles for stromelysine 3 : denaturation $=94^{\circ} \mathrm{C}, 45 \mathrm{sec}$; hybridization $=55^{\circ} \mathrm{C}, 45 \mathrm{sec}$; and elongation $=72^{\circ} \mathrm{C}, 45 \mathrm{sec}$. PCR products were separated on agarose gels and stained with ethidium bromide. The gels were then transferred onto a Hybond $\mathrm{N}$ nylon membrane (Amersham Pharmacia Biotech, Arlington Heights, IL, USA) overnight in a solution of $0.5 \mathrm{M} \mathrm{NaOH}$, and $1.5 \mathrm{M} \mathrm{NaCl}$. DNA was fixed on the membrane by UV exposure $\left(0.360 \mathrm{~J} / \mathrm{cm}^{2}\right)$. Oligonucleotides specific for each PCR fragment were labeled by $\gamma_{-}{ }^{32} \mathrm{P}$ ATP using T4 polynucleotide kinase from GibcoBRL and the conditions and buffers recommended by the enzyme supplier. The labeled oligonucleotides were purified on microspin G-50 columns (Pharmacia, Arlington Heights, IL, USA). After prehybridization $\left(1 \mathrm{~h}\right.$ at $\left.37^{\circ} \mathrm{C}\right)$, hybridization was carried out overnight at $37^{\circ} \mathrm{C}$ with $500 \mathrm{ng}$ of labeled oligonucleotide I. Subsequently, the membranes were rinsed several times for $10 \mathrm{~min}$ at $37^{\circ} \mathrm{C}$ and exposed with a phosphoimager film for about $12 \mathrm{~h}$. The pixel quantification of 
each band was performed using the IQMac v1.2 software from Molecular Dynamics. For data analysis, the normalized ratios of target gene to 28S rRNA were log transformed and the means were calculated. Differences between means were analyzed by ANOVA and the Tukey-Kramer test, differences were considered significant at $\left(^{*}\right) P \leq 0.05$ and $\left({ }^{* *}\right) P \leq 0.01$.

\section{TH effect on morphology in larval Necturus}

Larval N. maculosus were collected from a canal off of the Connecticut River in Turner's Falls, MA, under scientific collecting permit \#200.04 SCRA, and transported to the University of Michigan 1 month before the experiment. Larvae were divided into two size classes representing larvae in their first and second year of growth. Size-matched animals within each class were assigned to either $\mathrm{T}_{3}$ or control groups $(n=6 /$ size class/treatment). We added $\mathrm{T}_{3}$ to the aquarium water to a final concentration of $200 \mathrm{~nm}$; the water was changed and the hormone was replenished every other day during the 14-day experimental period. Treatment with $\mathrm{T}_{3}$ caused significant metamorphic changes over a similar time period in the salamander Amystoma trigrinum (Norris and Platt 1974). We treated $X$. laevis tadpoles (stage 56; $n=3 /$ treatment) with $200 \mathrm{nM} \mathrm{T}_{3}$ derived from the same stock solution to verify its activity. We measured mass, body length, tail fin height, and gill area of $\mathrm{Ne}$ cturus larvae before and after hormone treatment. We also captured digital images of each animal before and after treatment for identification and for measurement of the area of the gill rachis and filaments using MetaMorph v6.2 imaging software (Universal Imaging Corporation, Downingtown, PA, USA). The sum of the left and right gill areas was compared among treatments. For each size/ age class, we used repeated measures ANOVA to determine differences in body mass and length between control and $\mathrm{T}_{3}$-treated animals; tail fin height and gill area were analyzed with repeated measures ANCOVA with body mass as a covariate. Time by treatment interaction terms at or below $P=0.05$ indicated significant $\mathrm{T}_{3}$ effects on morphology.

\section{RESULTS}

We isolated and sequenced full-length cDNAs encoding $T R \alpha$ and $T R \beta$ from Necturus. The protein sequences were aligned with vertebrate TRs (supplementary Fig. S1). Necturus TR $\alpha$ exhibits $96.5 \%$ and $90.6 \%$ amino acid identity with Xenopus $T R \alpha$, in the DNA- and ligand-binding domains, respectively, whereas it bears $93.2 \%$ and $88.6 \%$ similarity to human $\mathrm{TR} \alpha$ in the same domains. Necturus TR $\beta$ is also similar to Xenopus $T R \beta(95.4 \%$ and $92.2 \%$ amino acid identity in DBD and LBD, respectively) and to a lesser extent to human $T R \beta$ (95.4\% and 90.2\%). In addition, the Necturus $T R \alpha$ and $T R \beta$ cDNAs are most similar to the $T R \alpha$ and $T R \beta$ sequences that we cloned from the axolotl, another neotenic urodele (Safi et al. 2004). These findings suggest that the sequences isolated are bona fide Necturus TR clones, not resulting from PCR contamination.
Necturus proteins exhibit all features of functional TRs. Within the LBD, the amino acids that are known to contact the ligand (based on 3D structure analysis; Wagner et al. 1995) directly are conserved, and both the dimerization interface of helix 9 and the transactivation domain AF2-AD located in helix 12 are strongly conserved. In addition, none of the mutations found in the $T R \beta$ gene in human cases of resistance to thyroid hormone syndrome were found (supplementary Fig. S1; Weiss and Refetoff 2000).

Using in vitro synthesized proteins in an electrophoretic mobility shift assay (EMSA), we found that all the proteins tested were able to bind to the XDR4 probe, a DR4 thyroid hormone response element (TRE) found in the promoter of the Xenopus TR $\beta$ gene (Ranjan et al. 1994; Machuca et al. 1995). Both $\operatorname{TR} \alpha$ and $\operatorname{TR} \beta$ were unable to bind to this element alone, but formed a strong heterodimer that bound to the XDR4 probe in the presence of the Xenopus $\mathrm{RXR} \alpha$ protein (Fig. 1A). Binding was displaced using competitors containing either direct repeats or palindromic TREs but not by a nonspecific oligonucleotide (Fig. 1). Thus, Xenopus and $\mathrm{Ne}$ cturus TRs have indistinguishable DNA binding and dimerization properties.

We next determined whether Necturus TR affinities for TH were similar to those of Xenopus TRs or human TR $\beta$. Scatchard analysis gave $K_{\mathrm{a}}$ values for $\mathrm{T}_{3}$ binding of $1 \times 10^{-10} \mathrm{M}$ for Necturus $\mathrm{TR} \alpha$ and $0.7 \times 10^{-10} \mathrm{M}$ for Necturus TR $\beta$. These values are very similar to those found for Xenopus and human TRs (Xenopus TR $\alpha K_{\mathrm{a}}=3.7 \times 10^{-10} \mathrm{M}$; Xenopus $\operatorname{TR} \beta \quad K_{\mathrm{a}}=2.9 \times 10^{-10} \mathrm{MM}$ and human $\operatorname{TR} \beta K_{\mathrm{a}}=1 \times$ $10^{-10}$ M) (Bonnelye et al. 1997). Thus, we conclude that $\mathrm{Ne}$ cturus and Xenopus receptors have similar affinities for $\mathrm{TH}$.

The transactivating properties of the Necturus and Xenopus TRs were assessed using transient transfection assays in rat osteosarcoma Ros 17.2/8 cells and a reporter gene containing the XDR4 element. Both $\mathrm{TR} \alpha$ and $\mathrm{TR} \beta$ proteins from Necturus and Xenopus repressed transcription in the absence of ligand and activated it with exogenous $\mathrm{T}_{3}$ (Fig. 2A). Xenopus and Necturus TRs activated transcription within the same range of hormone concentrations $\left(\mathrm{EC}_{50}\right.$ values were $2 \times 10^{-10} \mathrm{M}$ for Necturus TR $\alpha$ and $5 \times 10^{-8} \mathrm{M}$ for Necturus TR $\beta$; Fig. 2B), suggesting no gross differences in transcriptional efficiency.

As the data suggest that Necturus TRs are conserved and functional, we performed RT-PCR experiments to detect $T R \alpha$ and $T R \beta$ transcripts in Necturus tissues. Both $T R \alpha$ and $T R \beta$ transcripts were found in several tissues including muscle and gill. Although it is generally difficult to compare levels between genes expression with RT-PCR, we always found, using several primer pairs that $T R \alpha$ was expressed at higher levels than $T R \beta$ (data not shown). In situ hybridization (ISH, Fig. 3A) revealed that $T R s$ were expressed in the brain, intestine, urinary bladder mucosa, and muscle of adult Necturus (for the brain, see Fig. 3A). In the brain, $T R$ expression was re- 


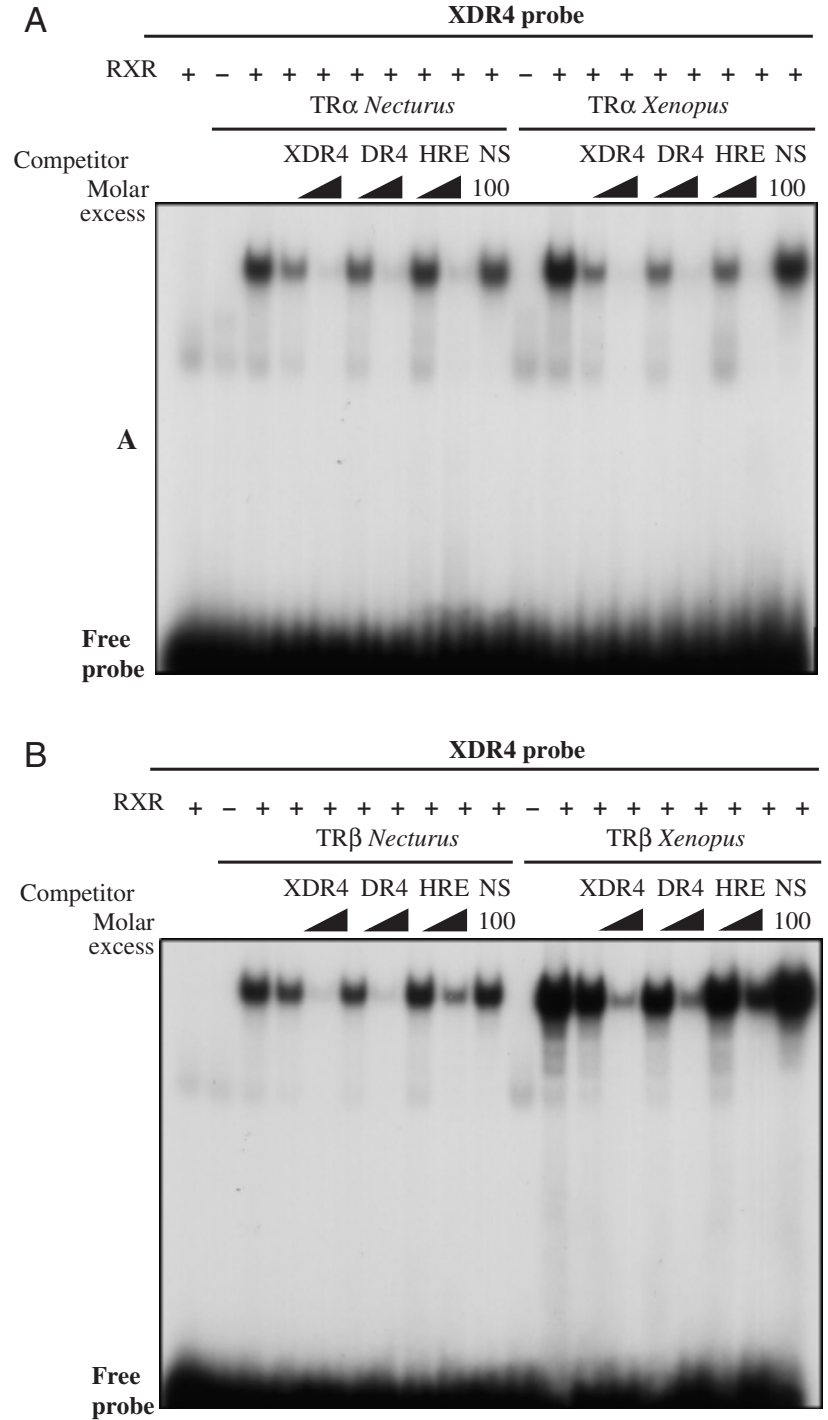

Fig. 1. Electrophoretic mobility shift assays. The labeled probe is the DR4 of the Xenopus TR $\beta$ promotor (XDR4). The experiments were performed with in vitro synthesized $\mathrm{TR} \alpha(\mathrm{A})$ or $\mathrm{TR} \beta(\mathrm{B})$ from Necturus (left) or Xenopus (right). When indicated, the in vitro synthetized Xenopus RXR $\alpha$ was added to allow dimerization with the TR. Competition experiments were performed with a 10- or 100-fold molar excess of a cold competitor such as XDR4, synthetic DR4 (DR4), palindromic hormone response element (HRE), or unrelated (NS) oligonucleotide.

stricted to the diencephalon $(T R \alpha)$ and to the cortical area of the telencephalon (both $T R \alpha$ and $T R \beta$ ). Muscle TR expression was found to be diffuse both in skeletal (tail, limb) and myocardial muscles.

To test whether TR proteins are expressed in vivo, we conducted immunohistochemistry using antiserums raised against synthetic peptides that correspond to regions of the Xenopus proteins that are conserved with Necturus (Fairclough and Tata 1997). We detected $\mathrm{TR} \alpha$ protein in the in-
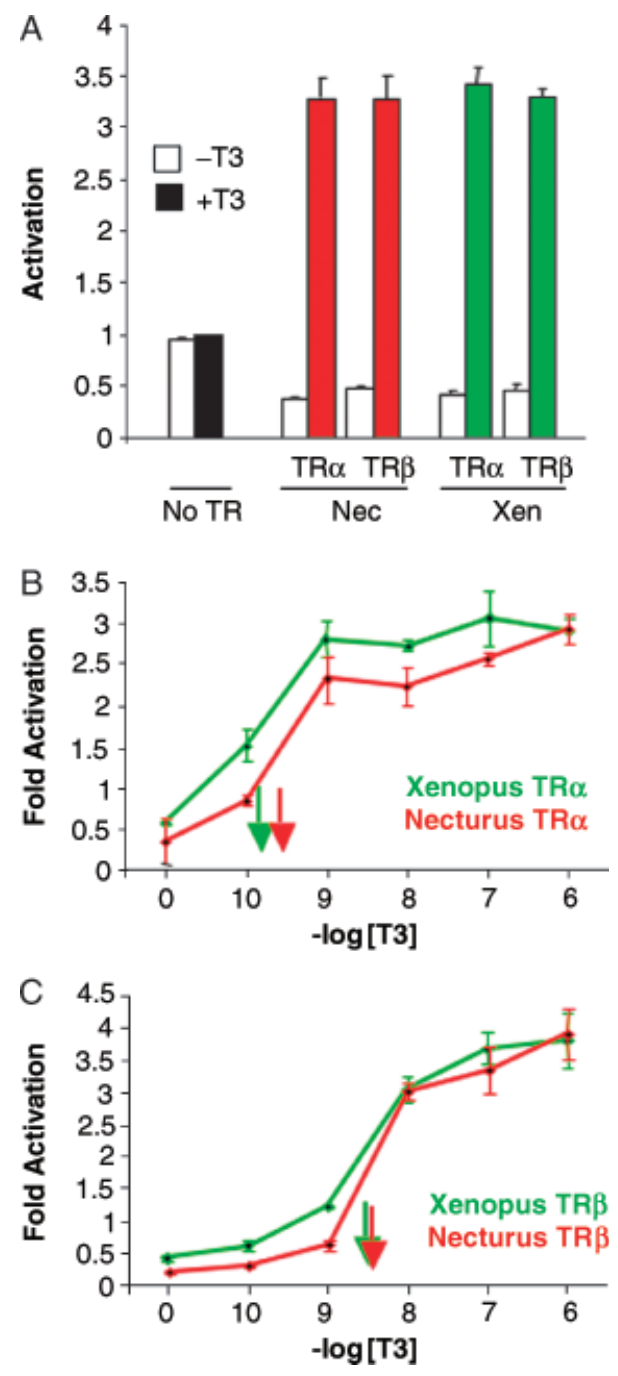

Fig. 2. (A) Transcriptional activity of Necturus and Xenopus TRs in response to $1 \mu \mathrm{M} \mathrm{T} \mathrm{T}_{3}$. pSG5, pSG5-TR $\alpha$, or pSG5-TR $\beta$ were transfected together with HRE-pal-pGL2 reporter construct in Ros cells, and $\mathrm{T}_{3}$ was added to the cell culture. The repressive effect of both $\operatorname{TR} \alpha$ and $\operatorname{TR} \beta$ in the absence of hormone is clearly visible for Necturus and Xenopus. (B) Dose-response experiments performed in Ros cells using the XDR4-pGL2 reporter vector. T3 concentrations tested were between $0.1 \mathrm{nM}$ and $1 \mu \mathrm{M}$. For both panels, the data from three independent experiments are depicted. The arrow indicates the concentration required to obtain an activation level of $50 \%$. HRE, hormone response element.

testinal epithelium, whereas no TR $\beta$ protein could be detected, probably because of low expression levels (Fig. 3B).

In addition to the TRs, we found that the brain, intestine, muscle, and gill of adult Necturus expressed TIF2, a TR transcriptional co-activator of the p160 family, and RXR $\alpha$ and $\beta$, the heterodimeric partners of the TRs (data not shown). We next tested for responses to $\mathrm{TH}$ at the molecular level. Adult Necturus were treated with $\mathrm{T}_{3}(5 \mathrm{nM}$ or $1 \mu \mathrm{M})$ in aquarium water for 1 month. These treatments raised circu- 
I
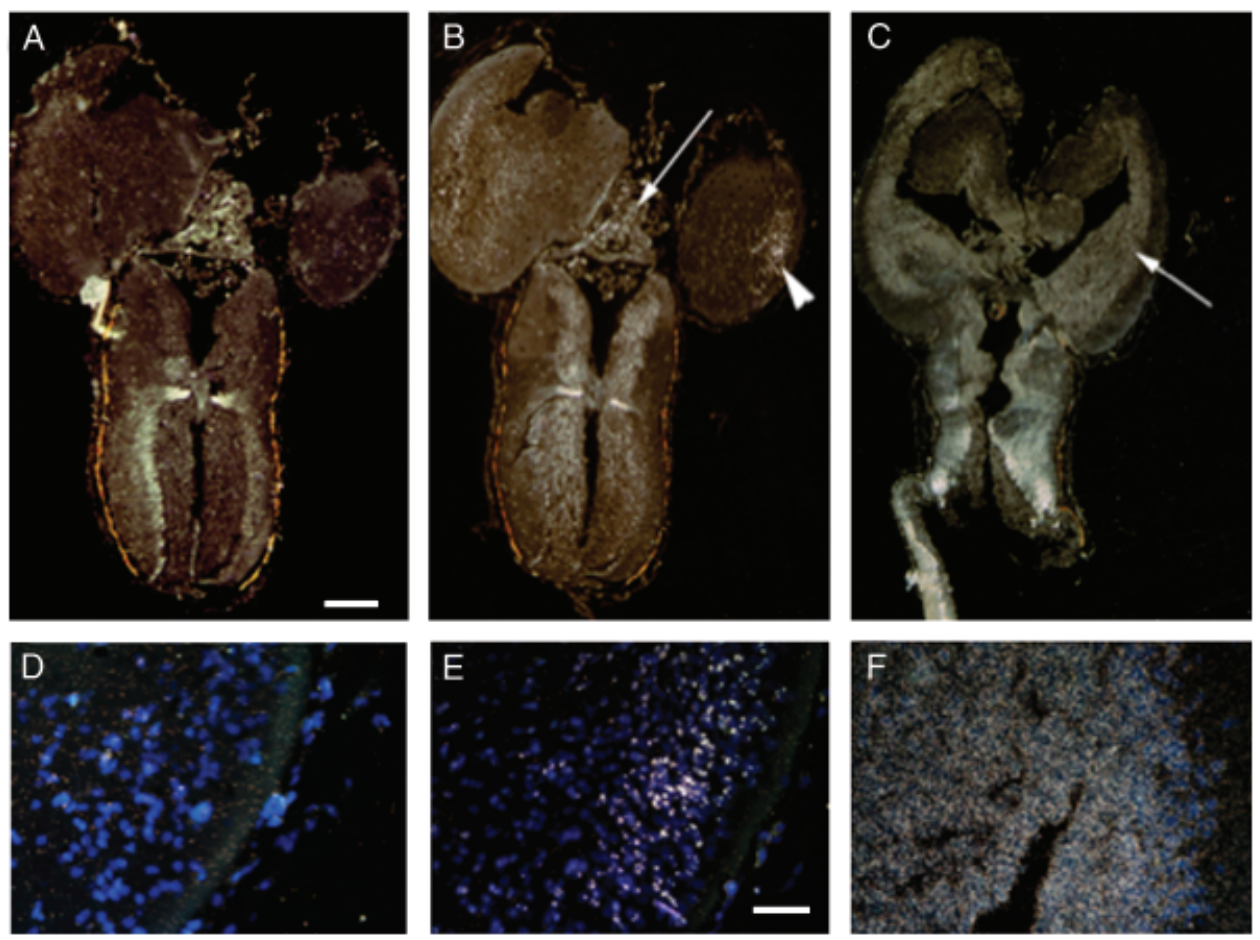
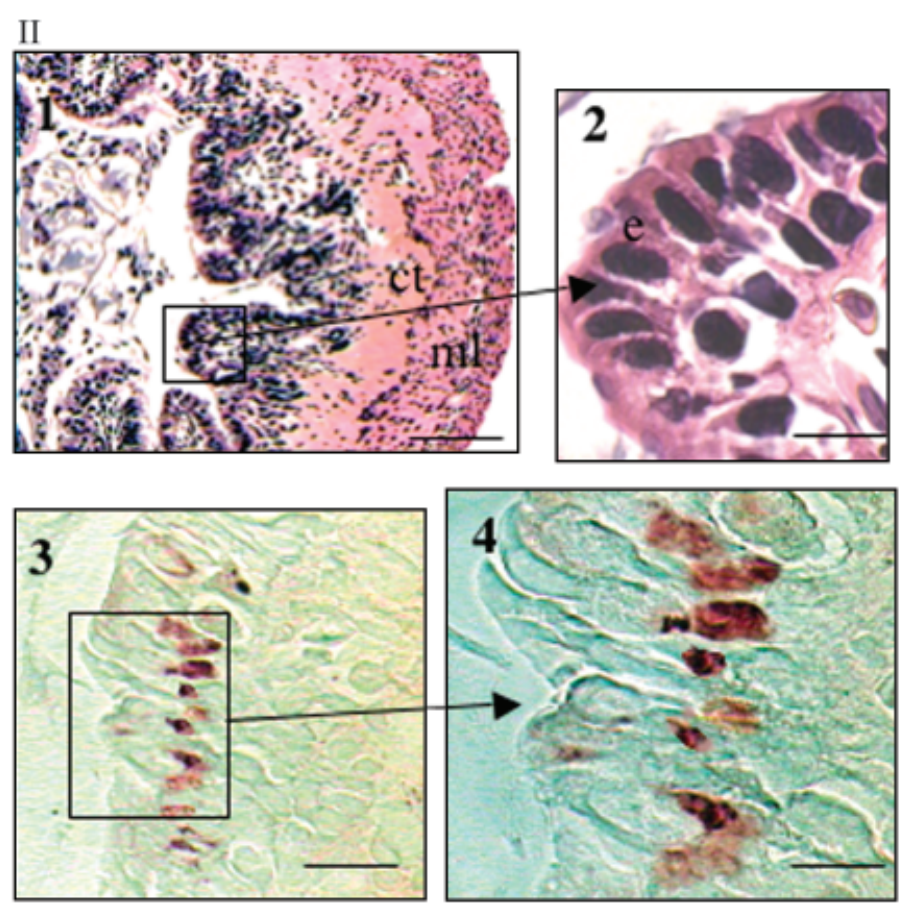

Fig. 3. (I) Expression of the TR genes in transverse sections of $\mathrm{Ne}$ cturus brain studied by in situ hybridization. Adjacent transverse sections (top = dorsal) were hybridized with sense $T R \alpha(\mathrm{A})$, antisense $T R \alpha(\mathrm{B})$, and antisense $T R \beta$ (C) probes $(\mathrm{bar}=600 \mu \mathrm{m})$. A higher magnification $(\mathrm{bar}=140 \mu \mathrm{m})$ was used for sections (D) (sense $\mathrm{TR} \alpha$ ), (E) (antisense $T R \alpha$ ) and (F) (antisense $T R \beta$ ) representing an end of the lateral ventricle. $T R \alpha$ gene is expressed in the diencephalic area $(\mathrm{B}$, arrow) and the cortical area of telencephalic vesicles (B, arrowhead), whereas $T R \beta$ is expressed in the periventricular area of telencephalic vesicles (C, arrow). (II) Expression of the TR proteins studied by immunohistochemistry using a Xenopus TR $\alpha$ antibody (Gould 1977; Mc Namara 1995). Morphological appearance of the Necturus intestine by hematoxylineosin histological staining (Hart and Wray 1999; Voss and Smith 2005). Adjacent sections have been stained with anti-TR $\alpha$ antibodies. The nuclear staining is clearly shown in the upper layer of the epithelium. 1, 3: bar $15 \mu \mathrm{m} ; 2,4$ : bar $6 \mu \mathrm{m}$. lating $\mathrm{T}_{3}$ concentrations from $0.19 \pm 0.06$ (controls) to $0.47 \pm 0.071$ and $126.2 \pm 11 \mathrm{ng} / \mathrm{ml}$ (means $\pm \mathrm{SEM}, n=6$ in each group) in the low-and high- $\mathrm{T}_{3}$ groups, respectively. The higher concentrations were supraphysiological, but it was important to achieve significantly increased levels of $\mathrm{T}_{3}$, at least equivalent to those seen during anuran metamorphosis (10- fold increases in circulating $\mathrm{T}_{3}$ concentrations; Voss and Smith 2005v). Expression of $S T 3, T R \alpha$, and $T R \beta$ in gills and intestine was monitored by a semiquantitative RT-PCR assay. ST3, $\operatorname{TR} \alpha$, and $\operatorname{TR} \beta$ levels were significantly up regulated in gill by $5 \mathrm{nM} \mathrm{T}_{3}$ (Fig. 4), but not by $1 \mu \mathrm{M} \mathrm{T}_{3}$. However, given the treatment duration, it is possible that the high $\mathrm{T}_{3}$ repressed 


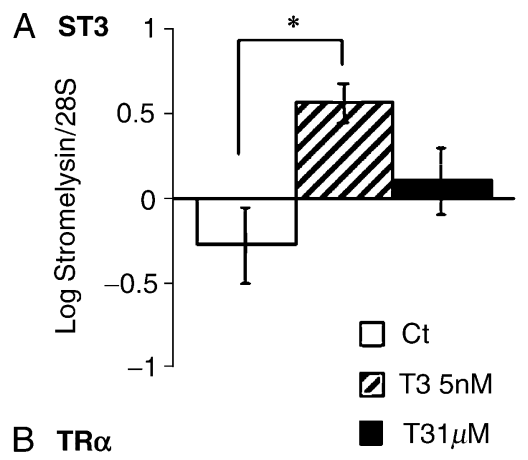

B TR $\alpha$
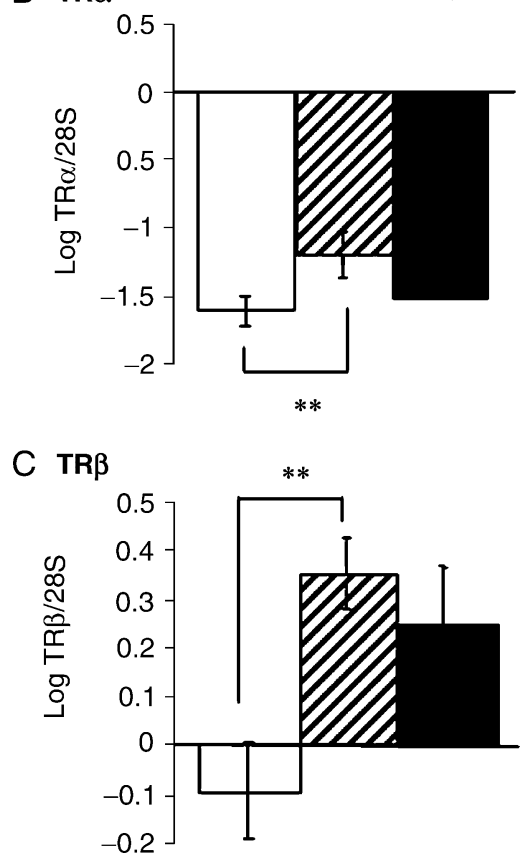

Fig. 4. TH treatment induces gene expression in Necturus gills. Animals were treated at two concentrations of T3 $(5 \mathrm{nM}$ and $1 \mu \mathrm{M})$ as described in the text. The level of Stromelysine 3 (A, ST3), TR $\alpha$ (B), and TR $\beta$ (C) mRNA in gills was assessed by semiquantitative RT-PCR. The results shown are from at least three independent experiments, each performed on at least five animals. Ratios of target gene to 28S rRNA were log transformed, and means were calculated. Differences between means were analyzed by ANOVA and the Tukey-Kramer test; differences were considered significant at $P \leq 0.5\left(^{*}\right)$ and $P \leq 0.01\left(^{* *}\right)$.TH, thyroid hormone.

gene expression, as reported previously (Lezoualc'h et al. 1995). Taken together, our data demonstrate that $T_{3}$ can up regulate genes in Necturus that are known to be $\mathrm{T}_{3}$ responsive in metamorphosing species. Interestingly, we found that other genes such as collagenase 4 and CTHBP were not regulated by TH (data not shown).

To address the possibility that adults become refractory to the metamorphic actions of $\mathrm{T}_{3}$, we exposed 1- and 2-year-old Necturus larvae ( $n=6 /$ class/treatment) to $200 \mathrm{nM} \mathrm{T}_{3}$ in the water (14 days). The same $\mathrm{T}_{3}$ solution caused tadpoles of $X$. laevis to undergo dramatic transformations in 4 days (data not shown). No significant changes in tail fin height or gill area of the Necturus larvae were seen. However, $\mathrm{T}_{3}$-treated first-year animals exhibited reduced growth and thus lower body weight compared with controls (repeated measures ANOVA time $\times$ treatment effect: body weight: $F_{(1,10)}=7.75$, $P<0.0193$; body length: $\left.F_{(1,10)}=19.40, P<0.0013\right)$. These results support our hypothesis that $\mathrm{T}_{3}$ has physiological effects in Necturus, in particular, a stimulation of catabolic pathways, but tissues that undergo regression in response to $T_{3}$ in metamorphosing species (i.e., tailfin and gills) are resistant to the hormone even during the larval stage.

\section{DISCUSSION}

Our results show that, in contrast with previously held concepts (Swingle 1922; Lynn 1961; Yaoita and Brown 1990), Necturus TR genes are expressed, the proteins are functional, and $\mathrm{TH}$ can induce gene expression changes in vivo. Thus, Necturus cannot be described as being generally resistant to the actions of TH. Two earlier reports support our findings. Galton (1985) reported high-affinity TH-binding sites in red blood cells $\left(K_{\mathrm{d}} 1.13 \times 10^{-11} \mathrm{M}\right)$, and Fox and Durand (1990) treated the related species, Proteus anguinus, with TH and observed weak effects on the skin. Our data, which show clear expression of TR $\alpha$ TR $\beta$, RXRs, and the coactivator TIF2, suggest that Necturus has the necessary molecular equipment to respond to TH. Indeed, we show that $\mathrm{TH}$ regulates the expression of certain endogenous genes in Necturus gill. It is noteworthy that we observed a clear autoinduction of the TR $\beta$ gene in Necturus gill, which is thought to be a necessary early event in the gene regulation cascade, leading to tissue transformation in metamorphosing species like $X$. laevis (Tata 1994).

The evolutionary conservation of the structure and function of Necturus TRs is nevertheless surprising, given that TH treatment induces no overt morphological changes in larvae or adults. This suggests that natural selection should act on these receptors with the same intensity as in metamorphosing amphibians. A similar conservation of structure and function of TRs was observed in the nonmetamorphosing Mexican axolotl (Safi et al. 2004). This suggests that the receptors retain essential functions that are independent of those involved in metamorphosis (at least the tissue resorption programs in gill and tail fin). It is possible that TH plays essential developmental roles in Necturus such as in brain maturation as is true in vertebrates generally, both metamorphosing and nonmetamorphosing (Denver 1998).

It should be emphasized that even though the TRs of $\mathrm{Ne}$ cturus are functional and expressed as they are in the axolotl (Safi et al. 2004), the mechanisms for the blockade of metamorphosis in the two species are different. Exogenous TH can produce transformation of the axolotl in which pedo- 
morphosis is facultative. In this species, the failure to undergo metamorphosis is probably linked to a defect in $\mathrm{TH}$ secretion (Taurog et al. 1974). Genetic experiments by Voss et al. (2000) rejected TRs as candidate genes for variation in the ambystomatid salamander life-history mode. There are other groups of Urodeles that exhibit alternative strategies regarding metamorphosis including pedomorphic species (e.g., Siren or Cryptobranchus). Given that these species appear in groups that are not directly related, this suggests that pedomorphosis appears several times independently in urodeles. Given the variety of mechanisms uncovered in Necturus and Ambysto$m a$, it would be interesting to study TH response and TR function in these species. Also, it has to be emphasized that our knowledge of the metamorphosis at the molecular level in classical transforming species (e.g., Pleurodeles waltii) is still low. Thus, the current lack of molecular data concerning TH response in Urodeles makes precise comparisons between transforming and pedomorphic species still difficult.

Earlier work that found that Necturus could not be induced to metamorphose by exogenous TH led to the hypothesis that the TRs in this species are not expressed or may not be functional. Given that Necturus has both a functional thyroid and functional TRs, detectable plasma TH (Charipper 1929; Grant 1930; Harris 1956; Rosenkilde and Ussing 1996), and $\mathrm{TH}$-dependent gene regulation, the question of the mechanisms that result in the obligate pedomorphic life-history mode must be re-addressed. As we found that TH induces gene expression in Necturus tissues, it is possible that the hormone causes some biochemical changes that are not evident at the level of organ morphology (e.g., the partial larval to adult fast isomyosin transition; Fox and Durand 1990). However, other TH response pathways such as gill or tail fin resorption are clearly not activated. This lack of response could be due to several possible molecular "defects." For example, the relevant target genes may have lost their ability to respond, in whole or in part, to $\mathrm{TH}$, perhaps through mutations in hormone response elements present in these genes (e.g., collagenase 3 among others). This implies that evolutionary changes in the Proteidae leading to the obligate pedomorphic life history occurred at the level of the TH-target genes. A key role for the evolution of target genes in the appearance of evolutionary novelties is well illustrated in arthropods. For example, the morphological differences between butterfly hind wings and Drosophila halters is not due to a gross difference in master control genes (i.e., Hox genes), but rather the master control genes regulate different gene hierarchies (Weatherbee et al. 1999). A related mechanism may have occurred during proteid salamander evolution; that is, a loss of thyroid hormone response elements in key metamorphic genes could account for the loss of TH action on tissue resorption. In this scenario, the obligate pedomorphic life-history mode in Necturus arose not by mutations in genes that control hormone production or hormone action (i.e., the
TRs), but as an indirect, pleiotropic consequence of natural selection acting on morphological or physiological characters. This is reminiscent of the situation in mammals, as a postembryonic perinatal period of high TH sensitivity has been observed by knockout of TRs in mouse, suggesting that in mammals a post-embryonic period of high TR expression and high TH levels leading to organ remodeling (e.g., intestine) is an attenuated version of metamorphosis (Fraichard et al. 1997).

A second, but not mutually exclusive, hypothesis is that the level of expression attained by TRs or accessory transcription factors (i.e., coactivators) in tissues such as the gill is not sufficient to support the full spectrum of TH action. In Xenopus tadpoles, the transforming tissues have different thresholds of response to $\mathrm{TH}$, the tail being relatively resistant (i.e., it requires high plasma $\mathrm{TH}$ levels for resorption to be triggered; 14, 15, 34), whereas gene expression and morphological changes in structures such as the brain or intestine require very low levels of thyroid hormone. These differences in tissue sensitivity in anuran tadpoles make adaptive sense in that the organism must prepare internal organs necessary for adult survival early in the metamorphic process, but should wait until late in the process to relinquish organs necessary for larval life such as the gill and tail (or tail fin). Thus, it may be that organs such as the brain or intestine that undergo remodeling in metamorphic species respond to TH in Necturus in a similar manner, whereas organs that normally disappear during metamorphosis have become insensitive to TH in obligate pedomorphs, perhaps owing to a failure to produce a sufficient level of TR (or coactivator) gene expression. To distinguish these mechanisms, future studies should focus on analyzing the molecular and morphological responses to $\mathrm{TH}$ in different Necturus tissues throughout development, and on comparing such effects with those that occur in metamorphosing urodeles. Attempts to rescue the metamorphic phenotype in specific Necturus tissues (e.g., apoptosis in gill) by ectopic expression of TR or coactivator genes may also be informative.

\section{ACKNOWLEDGMENTS}

We thank Michael Schubert, Hector Escriva, and François Bonneton for critically reading the article. We are extremely grateful to Gabrielle Planelles for providing Necturus animals, and Stéphanie Bertrand for help in measurement of TH levels in Necturus. R. S. holds a fellowship from the Ligue Nationale contre le Cancer. We thank MENRT (ACI program "Biologie du développement et Physiologie"), CNRS, ARC, and Ligue Régionale Contre le Cancer du Rhône et de la Loire for financial support. This research was supported in part by a grant from the National Science Foundation of the USA (IBN 0235401) to R. J. D.

\section{REFERENCES}

Berry, D. L., Rose, C. S., Remo, B. F., and Brown, D. D. 1998. The expression pattern of thyroid hormone response genes in remodeling 
tadpole tissues defines distinct growth and resorption gene expression programs. Dev. Biol. 203: 24-35.

Berry, D. L., Schartzman, R. A., and Brown, D. D. 1998. The expression pattern of thyroid hormone response genes in the tadpole tail identifies multiple resorption programs. Dev. Biol. 203: 12-23.

Bonnelye, E., et al. 1997. Expression pattern of the Estrogen related receptor 1 (ERR-1) orphan receptor during mouse development. Mech. Dev. 65: 71-85.

Charipper, H. A. 1929. Studies on amphibian endocrines. V. Accelerated metamorphosis of Rana clamitans larvae by means of implants of fresh anterior pituitary from adult Necturus maculosus. Anat. Rec. 44: 117141.

Denver, R. J. 1998. Molecular basis of thyroid hormone-dependent central nervous system remodeling during amphibian metamorphosis. Comp. Biochem. Physiol. C-Pharmacol. Toxicol. Endocrinol. 119: 219-228.

Fairclough, L., and Tata, J. R. 1997. An immunocytochemical analysis of the expression of thyroid hormone receptor alpha and beta proteins during natural and thyroid hormone-induced metamorphosis in Xenopus. Dev. Growth Differ. 39: 273-283.

Fox, H., and Durand, J. 1990. Observations on post-embryonic development in Proteus anguinus. Eur. Arch. Biol. 101: 269-284.

Fraichard, A., et al. 1997. The T3R alpha gene encoding a thyroid hormone receptor is essential for post-natal development and thyroid hormone production. EMBO J. 16: 4412-4420.

Galton, V. A. 1985. 3,5,3'-Triiodothyronine receptors and thyroxine $5^{\prime}$ monodeiodinating activity in thyroid hormone-insensitive amphibia. Gen. Comp. Endocrinol. 57: 465-471.

Galton, V. A., and Ingbar, S. H. 1962. Observations on the effects and the metabolism of thyroid hormones in Necturus maculosus. Endocrinology 71: 369-377.

Gould, S. J. 1977. Ontogeny and Phylogeny. Harvard University Press, Cambridge, MA.

Grant, M. P. 1930. The release of follicular colloid from the thyroid of Necturus maculosus following heteroplastic anterior-pituitary implants. Anat. Rec. 46: 205-221.

Harris Jr., J. P. 1956. Neoteny in amphibians. Field Lab. 24: 21-26.

Hart, M. W., and Wray, G. A. 1999. In B. K. Hall and M. H. Wake (eds.). The Origins and Evolution of Larval Forms. Academic Press, New York, pp. 159-168.

Helbing, C. C., Werry, K., Crump, D., Domanski, D., Veldhoen, N., and Bailey, C. M. 2003. Expression profiles of novel thyroid hormoneresponsive genes and proteins in the tail of Xenopus laevis tadpoles undergoing precocious metamorphosis. Mol. Endocrinol. 17: 1395-1409.

Kanamori, A., and Brown, D. D. 1992. The regulation of thyroid hormone receptor beta genes by thyroid hormone in Xenopus laevis. J. Biol. Chem. 267: 739-745.

Leloup, J., and Buscaglia, M. 1977. La triiodothyronine: hormone de la métamorphose des Amphibiens. C. R. Hebd. Séances Acad. Sci. Ser. D 284: 2261-2265.

Lezoualc'h, F., Seugnet, I., Monnier, A. L., Ghysdael, J., Behr, J. P., and Demeneix, B. A. 1995. Inhibition of neurogenic precursor proliferation by antisense alpha thyroid hormone receptor oligonucleotides. J. Biol. Chem. 270: 12100-12108.

Lynn, W. G. 1961. Types of amphibian metamorphosis. Am. Zool. 1: 151162.

Machuca, I., Esslemont, G., Fairclough, L., and Tata, J. R. 1995. Analysis of structure and expression of the Xenopus thyroid hormone receptorbeta gene to explain its autoinduction. Mol. Endocrinol. 9: 96-107.

Mc Namara, K. J. (eds.). 1995. Evolutionary Change and Heterochrony. Wiley, New York.

Norris, D. O., and Platt, J. E. 1974. T3- and T4-induced rates of metamorphosis in immature and sexually mature larvae of Ambystoma tigrinum (Amphibia: Caudata). J. Exp. Zool. 189: 303-310.

Ochman, H., Gerber, A. S., and Hartl, D. L. 1988. Genetic applications of an inverse polymerase chain reaction. Genetics 120: 621-623.
Ranjan, M., Wong, J., and Shi, Y-B. 1994. Transcriptional repression of Xenopus TR beta gene is mediated by a thyroid hormone response element located near the start site. J. Biol. Chem. 269: 24699-24705.

Rosenkilde, P., and Ussing, A. P. 1996. What mechanisms control neoteny and regulate induced metamorphosis in urodeles? Int. J. Dev. Biol. 40: $665-673$.

Safi, R., Bègue, A., Hänni, C., Stéhelin, D., Tata, J. R., and Laudet, V. 1997. Thyroid Hormone Receptors in neotenic amphibians. J. Mol. Evol. 44: 595-604.

Safi, R., et al. 2004. The axolotl (Ambystoma mexicanum), a neotenic amphibian expresses functional thyroid hormone receptors. Endocrinology 145: 760-762.

Shi, Y.-B. 1999. Amphibian Metamorphosis. From Morphology to Molecular Biology. John Wiley \& Sons Inc., New York, 288pp.

Swingle, W. W. 1922. Experiments on the metamorphosis of neotenous amphibians. J. Exp. Zool. 36: 397-405.

Tata, J. R. 2000. Autoinduction of nuclear hormone receptors during metamorphosis and its significance. Insect Bioch. Mol. Biol. 30: 645-651.

Tata, J. R. 1994. Autoregulation and crossregulation of nuclear receptor genes. Trends Endocrinol. Metab. 5: 283-290.

Taurog, A., Oliver, C., Eskay, R. L., Porter, J. C., and McKenzie, J. M. 1974. The role of TRH in the neoteny of the Mexican axolotl (Ambystoma mexicanum). Gen. Comp. Endocrinol. 24: 267-279.

Triglia, T., Peterson, M. G., and Kemp, D. J. 1988. A procedure for in vitro amplification of DNA segments that lie outside the boundaries of known sequences. Nucleic Acids Res. 16: 8186.

Voss, S. R., Shaffer, H. B., Taylor, J., Safi, R., and Laudet, V. 2000. Candidate gene analysis of thyroid hormone receptors in metamorphosing vs. nonmetamorphosing salamanders. Heredity 85: 107-114.

Voss, S. R., and Smith, J. J. 2005. Evolution of salamander life cycles: A major-effect quantitative trait locus contributes to discrete and continuous variation for metamorphic timing. Genetics 170: 275-281.

Wagner, R. L., Apriletti, J. W., McGrath, M. E., West, B. L., Baxter, J. D., and Fletterick, R. J. 1995. A structural role for hormone in the thyroid hormone receptor. Nature 378: 690-697.

Weatherbee, S. D., et al. 1999. Ultrabithorax function in butterfly wings and the evolution of insect wing patterns. Curr. Biol. 11: 109-115.

Weiss, R. E., and Refetoff, S. 2000. Resistance to thyroid hormone. Rev. Endocr. Metab. Disord. 1: 97-108.

Yaoita, Y., and Brown, D. D. 1990. A correlation of thyroid hormone receptor gene expression with amphibian metamorphosis. Genes Dev. 4: $1917-1924$.

\section{SUPPLEMENTARY MATERIAL}

The following supplementary material is available for this article online:

Fig. S1. Amino acid sequence alignment of $T R \alpha$ and $T R \beta$ from rat or human, Xenopus laevis and Necturus maculosus. The various structural domains and their boundaries are indicated. In the DBD the helices and the P- and D-boxes are underlined and boxed, respectively. For the ligand-binding domain (also called E domain) the 12 helices found in the 3D structure of the mammalian TRs are indicated. The amino acids of the LBD that directly contact the ligand in the 3D structure (Wagner et al. 1995) are boxed. Those that have been found mutated in humans with resistance to TH are highlighted in red.

Table S1. Oligonucleutides used in this study. 